\title{
Phylogenetic analysis and delineation of phytoplasmas based on secY gene sequences
}

Correspondence
I.-M. Lee
ingming.lee@ars.usda.gov

\author{
I.-M. Lee, ${ }^{1}$ K. D. Bottner-Parker, ${ }^{1}$ Y. Zhao, ${ }^{1}$ R. E. Davis ${ }^{1}$ and N. A. Harrison ${ }^{2}$ \\ ${ }^{1}$ Molecular Plant Pathology Laboratory, USDA, ARS, Beltsville, MD 20705, USA \\ ${ }^{2}$ FLREC, University of Florida, Fort Lauderdale, FL 33314, USA
}

\begin{abstract}
The sec $Y$ gene sequence is more variable than that of the $16 \mathrm{~S}$ rRNA gene. Comparative phylogenetic analyses with $16 \mathrm{~S}$ rRNA and $\sec Y$ gene sequences from 80 and 83 phytoplasma strains, respectively, were performed to assess the efficacy of these sequences for delineating phytoplasma strains within each $16 \mathrm{Sr}$ group. The phylogenetic interrelatedness among phytoplasma taxa inferred by $\sec Y$ gene-based phylogeny was nearly congruent with that inferred by $16 \mathrm{~S}$ rRNA gene-based phylogeny. Phylogenetic analysis based on the sec $Y$ gene permitted finer differentiation of phytoplasma strains, however. The sec $Y$ gene-based phylogeny not only readily resolved $16 \mathrm{Sr}$ subgroups within a given $16 \mathrm{Sr}$ group, but also delineated distinct lineages irresolvable by $16 \mathrm{~S}$ rRNA gene-based phylogeny. Such high resolving power makes the $\sec Y$ gene a more useful genetic marker than the 16S rRNA gene for finer differentiation of closely related phytoplasma strains based on RFLP analysis with selected restriction enzymes. Such strains were readily identified by collective secY RFLP patterns. The genetic interrelationships among these strains were determined by pattern similarity coefficients, which coincided with delineations by phylogenetic analysis. This study also revealed two heterogeneous $s p c$ operons present in the phytoplasma clade. This latter finding may have significant implications for phytoplasma evolution.
\end{abstract}

\section{INTRODUCTION}

Phytoplasmas, formerly termed mycoplasma-like organisms (MLOs), are minute, cell-wall-less prokaryotes that are associated with diseases in several hundred plant species (Lee et al., 2000; Bertaccini, 2007; Hogenhout et al., 2008). Extensive phylogenetic studies have placed phytoplasmas in the class Mollicutes. Because it has proved impossible to obtain pure cultures of any phytoplasma and the paucity of accessible phenotypic criteria, it is difficult to classify phytoplasmas according to the criteria applied to taxonomy of the Mollicutes (Weisburg et al., 1989; Murray \& Schleifer, 1994; Vandamme et al., 1996; Razin et al., 1998), and phytoplasma taxonomy is inevitably based heavily on molecular characteristics and phylogeny. The $16 \mathrm{~S}$ rRNA gene sequence has been used as the primary parameter for differentiation and classification of phytoplasmas (Lee et al., 1993b, 1998a; Schneider et al., 1995; Seemüller et al., 1994, 1998). So far, a total of 19 distinct groups based on actual RFLP analysis of PCR-amplified $16 \mathrm{~S}$ rRNA gene sequences, termed $16 \mathrm{~S}$ rRNA groups (16Sr groups), or 30 groups based on in silico RFLP analysis have been identified (Lee et al., 1998a, 2000; Wei et al., 2007). Eighty-nine $16 \mathrm{Sr}$ subgroups were further classified by in

The GenBank/EMBL/DDBJ accession numbers for the sequences determined in this study are given in Table 1. silico analysis. The latter RFLP-based grouping is highly consistent with phylogenetic relationships based on analysis of $16 \mathrm{~S}$ rRNA gene sequences. It was proposed that each 16S rRNA gene RFLP group represents at least one phytoplasma species (Gundersen et al., 1994). At present, species designation is based primarily on dissimilarity of $16 \mathrm{~S}$ rRNA gene sequences among phytoplasmas. An arbitrary threshold of $2.5 \%$ dissimilarity was applied as a guideline for erecting a novel species (IRPCM Phytoplasma/ Spiroplasma Working Team - Phytoplasma Taxonomy Group, 2004). Because of the highly conserved nature of the 16S rRNA gene, this guideline may exclude many ecologically or biologically distinct phytoplasma strains, some of which may warrant designation as novel taxa.

Classification of distinct strains below the species level has been based primarily on RFLP analysis of 16S rRNA gene sequences. Over the last decade, epidemiological studies have revealed that diverse phytoplasma strains, which are very closely related based on analysis of $16 \mathrm{~S}$ rRNA gene sequences, are involved in similar diseases associated with different cultivars of a given plant species grown in the same or different geographical regions (Martini et al., 2002; Lee et al., 2003, 2004c, 2006b). It is not uncommon that closely related phytoplasma strains have unique ecological niches encompassing both plant host range and insect vectors (Lee et al., 1998b, 2000). 
Table 1. Phytoplasma strains used in this study

'Ca. P.', 'Candidatus Phytoplasma'.

\begin{tabular}{|c|c|c|c|c|c|}
\hline \multirow[t]{2}{*}{ Strain } & \multirow[t]{2}{*}{ Associated disease(s) } & \multirow{2}{*}{$\begin{array}{c}\text { Geographical } \\
\text { origin }\end{array}$} & \multirow{2}{*}{$\begin{array}{c}\text { 16S rRNA gene } \\
\text { RFLP classification }\end{array}$} & \multicolumn{2}{|c|}{ GenBank accession number(s) } \\
\hline & & & & 16S rRNA gene & $\sec Y$ \\
\hline $\mathrm{BB}$ & Tomato big bud & Arkansas, USA & 16SrI-A & AY180955 & AY803178 \\
\hline NJAY & New Jersey aster yellows & New Jersey, USA & 16 SrI-A & - & GU004345* \\
\hline GD1 & Grey dogwood stunt & New York, USA & 16 SrI-A & DQ112021 & AY803171 \\
\hline CHRYM & Chrysanthemum yellows & Germany & 16SrI-A & AY265214 & AY803170 \\
\hline HYDP & Hydrangea phyllody & Belgium & 16SrI-A & AY265215 & AY803181 \\
\hline PVM & Plantago virescence & Germany & 16 SrI-A & AY265216 & AY803185 \\
\hline ‘Ca. P. asteris’ AYWB & Aster yellow witches'-broom & Ohio, USA & 16SrI-A & NC_007716 & NC_007716 \\
\hline AY (AY1) & Maryland aster yellows & Maryland, USA & 16 SrI-B & AF322644 & AY803177 \\
\hline $\mathrm{CY}$ & Chrysanthemum yellow & Italy & 16 SrI-B & EF634457 & DQ787851 \\
\hline $\mathrm{HyPH}$ & Hydrangea phyllody & Italy & 16 SrI-B & AY265207 & AY803173 \\
\hline PRIVC & Primrose virescence & Germany & 16SrI-B & AY265210 & AY803176 \\
\hline OAY & Oenothera virescence & Michigan, USA & 16 SrI-B & M30790 & - \\
\hline AV2192 & Aster yellows & Germany & 16SrI-B & AY180957 & AY803167 \\
\hline MBS & Maize bushy stunt & Mexico & 16 SrI-B & AY265208 & $\begin{array}{l}\text { AY803175; } \\
\text { GU004341* }\end{array}$ \\
\hline $\mathrm{CPh}-\mathrm{a}$ & Clover phyllody & Canada & $16 \mathrm{SrI}-\mathrm{C}$ & AF222065 & $\begin{array}{l}\text { AY803179; } \\
\text { GU004339* }\end{array}$ \\
\hline KVG & Clover phyllody & Germany & 16 SrI-C & AY265218 & AY803183 \\
\hline KVE & Clover phyllody & France & 16SrI-C & AY265217 & AY803174 \\
\hline PaWB & Paulownia witches'-broom & Taiwan & 16SrI-D & AY265206 & $\begin{array}{l}\text { AY803184; } \\
\text { GU004337* }\end{array}$ \\
\hline BBS3 & Blueberry stunt & Michigan, USA & 16SrI-E & AY265213 & $\begin{array}{l}\text { AY803169; } \\
\text { GU004357* }\end{array}$ \\
\hline ACLR-AY & Apricot chlorotic leaf roll & Spain & 16 SrI-F & AY265211 & AY803166 \\
\hline CVB & Leafhopper borne & Germany & 16 SrI-F & AY265212 & AY803172 \\
\hline STRAWB2 & Strawberry multiplier & Florida, USA & $16 S r I-K$ & U96616 & AY803180 \\
\hline AVUT & Aster yellows & Germany & 16SrI-M & AY265209 & AY803168 \\
\hline IOWB & Ipomoea obscura witches'-broom & Taiwan & $16 S r I-N$ & AY265205 & AY803182 \\
\hline PnWB & Peanut witches'-broom & Taiwan & 16SrII-A & L33765 & GU004331* \\
\hline SPWB & Sweet potato witches'-broom & Taiwan & 16SrII-A & L33770 & GU004321* \\
\hline SEPN & Sesame phyllody & Thailand & 16SrII-A & EF193357 & GU004362* \\
\hline SEPT & Sesame phyllody & Thailand & 16SrII-A & GU004373† & GU004322* \\
\hline CaWBYN16 & Cactus witches'-broom YN16 & China & 16SrII-C & EU099561 & GU004323* \\
\hline SOYP & Soybean phyllody & Thailand & 16SrII-C & EF193353 & GU004324* \\
\hline $\mathrm{CrP}$ & Crotalaria phyllody & Unknown & 16SrII-C & EF193355 & GU004349* \\
\hline $\mathrm{CoP}$ & Cotton phyllody & Unknown & 16SrII-C & EF186827 & GU004350* \\
\hline PEP & Picris echioides phyllody & Italy & 16SrII-E & Y16393 & GU004348* \\
\hline TBB & Australian tomato big bud & Australia & 16SrII-D & Y08173 & GU004347* \\
\hline CX & Peach X-disease & Canada & 16SrIII-A & L33733 & GU004327* \\
\hline WX & $\mathrm{X}$-disease & Canada & 16SrIII-A & L04682 & GU004354* \\
\hline CYE & Clover yellow edge & Lithuania & 16SrIII-B & AF173558 & GU004332* \\
\hline Vac & Vaccinium witches'-broom & Germany & 16SrIII-F & X76430 & GU004360* \\
\hline PBT & Pecan bunchy top & Georgia & 16SrIII-C & GU004371 $\dagger$ & GU004361* \\
\hline GR1 & Goldenrod yellows & New York, USA & 16SrIII-D & GU004372† & GU004364* \\
\hline SP1 & Spirea stunt & New York, USA & 16SrIII-E & AF190228 & GU004326* \\
\hline MW1 & Milkweed yellows & New York, USA & $16 \mathrm{SrIII}-\mathrm{F}$ & AF510724 & GU004340* \\
\hline AKpot7 & Potato purple top-AK & Alaska, USA & 16SrIII-F & GU004370 $0^{\dagger}$ & GU004358* \\
\hline WWB & Walnut witches'-broom & Georgia, USA & 16SrIII-G & AF190227 & GU004325* \\
\hline JR1Ph (PoiBI) & Poinsettia branch inducing & USA & 16 SrIII-H & AF190223 & GU004328* \\
\hline MT117 & Potato purple top-MT & Montana, USA & 16SrIII-M & FJ226074 & GU004333* \\
\hline AKpot6 & Potato purple top-AK & Alaska, USA & 16 SrIII-N & GU004365† & GU004359* \\
\hline LYF (LYF-C5) & Coconut lethal yellows & Florida, USA & 16SrIV-A & AF498308 & GU004320* \\
\hline
\end{tabular}


Table 1. cont.

\begin{tabular}{|c|c|c|c|c|c|}
\hline \multirow[t]{2}{*}{ Strain } & \multirow[t]{2}{*}{ Associated disease $(s)$} & \multirow{2}{*}{$\begin{array}{l}\text { Geographical } \\
\text { origin }\end{array}$} & \multirow{2}{*}{$\begin{array}{l}\text { 16S rRNA gene } \\
\text { RFLP classification }\end{array}$} & \multicolumn{2}{|c|}{ GenBank accession number(s) } \\
\hline & & & & $16 S$ rRNA gene & $\sec Y$ \\
\hline ‘Ca. P. ulmi’ EY1 & Elm yellows & New York, USA & $16 \mathrm{SrV}-\mathrm{A}$ & AY197655 & $\begin{array}{l}\text { AY197690; } \\
\text { GU004330* }\end{array}$ \\
\hline $\begin{array}{l}\text { ‘Ca. P. ulmi’ EYEu } \\
\text { (EY-626) }\end{array}$ & Elm yellows & Italy & $16 \mathrm{SrV}-\mathrm{A}$ & AY197657 & AY197691 \\
\hline CLY5 & Cherry lethal yellows & China & $16 \mathrm{SrV}-\mathrm{B}$ & AY197659 & AY197693 \\
\hline PY-In & Peach yellows & India & $16 \mathrm{SrV}-\mathrm{B}$ & AY197660 & AY197694 \\
\hline 'Ca. P. ziziphi' JWB & Jujube witches'-broom & China & $16 \mathrm{SrV}-\mathrm{B}$ & AY197661 & AY197695 \\
\hline ALY882 & Alder yellows & Germany & $16 \mathrm{SrV}-\mathrm{C}$ & AY197642 & AY197692 \\
\hline FD70 & Flavescence dorée & France & $16 \mathrm{SrV}-\mathrm{C}$ & AY197643 & AY197686 \\
\hline FD-C & Flavescence dorée & Italy & $16 \mathrm{SrV}-\mathrm{C}$ & AY197645 & AY197688 \\
\hline ALY & Alder yellows & Italy & $16 \mathrm{SrV}-\mathrm{C}$ & AY197646 & AY197684 \\
\hline SpaWB229 & Spartium witches'-broom & Italy & $16 \mathrm{SrV}-\mathrm{C}$ & AY197652 & AY197689 \\
\hline HD1 & Hemp dogbane & New York, USA & $16 \mathrm{SrV}-\mathrm{C}$ & AY197654 & AY197687 \\
\hline FD-D & Flavescence dorée & Italy & $16 \mathrm{SrV}-\mathrm{D}$ & AY197644 & AY197685 \\
\hline RuS & Rubus stunt & Italy & $16 \mathrm{SrV}-\mathrm{E}$ & AY197648 & AY197696 \\
\hline 'Ca. P. trifolli' CP & Clover phyllody & Canada & 16SrVI-A & AY500130 & GU004315* \\
\hline 'Ca. P. trifolli' PWB & Potato witches'-broom & Canada & 16SrVI-A & AY500818 & GU004316* \\
\hline VR & Vinca virescence & California, USA & 16SrVI-A & AY500817 & GU004317* \\
\hline LUM & Lucerne virescence & France & 16SrVI-A & EF186821 & GU004318* \\
\hline AkPot1 & Potato purple top-AK & Alaska, USA & 16SrVI-A & GU004366† & GU004351* \\
\hline AKpot2 & Potato purple top-AK & Alaska, USA & 16SrVI-A & GU004367† & GU004342* \\
\hline AKpot4 & Potato purple top-AK & Alaska, USA & 16SrVI-A & GU004368† & GU004343* \\
\hline AKpot5 & Potato purple top-AK & Alaska, USA & 16SrVI-A & GU004369† & GU004344* \\
\hline DBPh2 & Dry bean phyllody & Washington, USA & 16SrVI-A & AY496002 & GU004352* \\
\hline DBPh3 & Dry bean phyllody & Washington, USA & 16SrVI-A & AY496003 & GU004353* \\
\hline BLL & Brinjal little leaf & India & 16SrVI-D & EF186820 & GU004356* \\
\hline AshY1 & Ash yellows & New York, USA & 16SrVII-A & AF092209 & GU004329* \\
\hline LfWB & Loofah witches'-broom & Taiwan & 16SrVIII-A & L33764 & GU004319* \\
\hline 'Ca. P. mali' AT & Apple proliferation & Germany & $16 \mathrm{SrX}-\mathrm{A}$ & CU469464 & CU469464 \\
\hline 'Ca. P. mali' AP15 & Apple proliferation & Italy & $16 \mathrm{SrX}-\mathrm{A}$ & EF193366 & GU004335* \\
\hline 'Ca. P. prunorum' PLN & $\begin{array}{l}\text { European stone fruit yellows/plum } \\
\text { leptonecrosis }\end{array}$ & Germany/Italy & 16SrX-B & AJ542545 & GU004334* \\
\hline 'Ca. P. pyri' PD1 & Pear decline & Italy & $16 \mathrm{SrX}-\mathrm{C}$ & AJ542543 & GU004363* \\
\hline STOL & Pepper stolbur & Serbia & 16SrXII-A & AF248959 & - \\
\hline Stolbur PO & Vinca stolbur & France & 16SrXII-A & - & FM163376 \\
\hline Rus93 & Stolbur-Rus & Russia & 16SrXII-A & GU004375† & GU004346* \\
\hline PTV & Stolbur-It & Italy & 16SrXII-A & GU004374† & GU004355* \\
\hline 'Ca. P. australiense' PYL & $\begin{array}{l}\text { Phormium yellow leaf/Australian } \\
\text { grapevine yellows }\end{array}$ & $\begin{array}{l}\text { New Zealand/ } \\
\text { Australia }\end{array}$ & 16SrXII-B & U43570 & NC_010544 \\
\hline MPV & Mexican periwinkle virescence & Mexico & 16SrXIII-A & AF248960 & GU004336* \\
\hline $\begin{array}{l}\text { 'Ca. P. americum’ } \\
\text { APPT10-NE }\end{array}$ & American potato purple top wilt & Nebraska, USA & 16SrXVIII-B & DQ174121 & GU004338* \\
\hline
\end{tabular}

${ }^{\star}$ Submitted as partial $s p c$ operon sequence in this study.

$\dagger 16 \mathrm{~S}$ rRNA gene sequence submitted in this study.

Often, such strains cannot be readily differentiated by analysis of $16 \mathrm{~S}$ rRNA gene sequences, hindering the development of targeted and efficient disease control measures and underscoring the need to seek additional markers that permit finer differentiation of closely related strains. In the last decade, several other conserved genes or specific genomic DNA fragments have been studied in the search for molecular markers for finer strain differentiation (Lee et al., 2006a; Marcone et al., 2000; Martini et al., 2007).

Earlier studies on differentiation of phytoplasma strains within the aster yellows group (16SrI) (Lee et al., 2006a) and the elm yellows group (16SrV) (Lee et al., 2004a) 
indicated that, because of its high resolving power, the $\sec Y$ gene, encoding a protein translocase subunit, represents one of the most promising markers for finer differentiation of phytoplasma strains and for delineating biologically and/ or ecologically distinct strains that often cannot be readily resolved by analysis of the 16S rRNA gene alone. Phylogenetic interrelationships based on $\sec Y$ gene analysis have not been explored for strains constituting the majority of phytoplasma groups. In the present study, comparative phylogenetic analyses were performed and phylogenetic trees constructed based on sequence analyses of $16 \mathrm{~S}$ rRNA and $\sec Y$ genes from representative phytoplasma strains in order to evaluate the efficacy of $\sec Y$ gene sequences for differentiation of closely related phytoplasma strains.

\section{METHODS}

Phytoplasma strains and nucleic acid preparation. Phytoplasma strains used in this study are listed in Table 1; they are representative of $1216 \mathrm{Sr}$ groups. Many of the phytoplasma strains were available in our inventory (as extracted total nucleic acid preparations). For those that were unavailable, total nucleic acid was extracted using leaf midribs or other tissues from periwinkle or original hosts that were infected by these phytoplasma strains according to the method described by Lee et al. (1993a) or Green et al. (1999). The strains were previously characterized and identified by RFLP or sequence analysis of the 16S rRNA gene (Bertaccini, 2007; Jacobs et al., 2003; Lee et al., 1993b, 1998a, 2000; Marcone et al., 1997a, b, c, 2000; Martini et al., 2007; Schneider et al., 1997; Seemüller et al., 1998; Cai et al., 2008).

Primer design. Degenerate primer pair L15F1/MapR1 (Table 2) was initially designed based on conserved regions of the ribosomal protein gene $r p l 15$ (or $r p l O$ ) and methionine aminopeptidase gene map in the $s p c$ ribosomal protein operon, which contains the rpll5 gene, the adenylate kinase gene $(a d k)$, a protein translocase gene $(\sec Y)$ and the map gene (Suh et al., 1996). Conserved regions were identified by alignment of sequences of the rpl15 and map genes from four phytoplasma and Acholeplasma strain genome sequences available in GenBank and the LY phytoplasma sequence (N. A. Harrison, unpublished) using CLUSTAL $\mathrm{V}$ from the LaserGene software MEGALIGN program (DNASTAR). Additional primers were designed within the L15F1/MapR1 amplicon to facilitate sequencing of the $s p c$ operon (Table 2). Subsequently, more specific primers were designed based on alignment of sequences from partial $s p c$ operons amplified from representative $16 \mathrm{Sr}$ group phytoplasmas using the primer pair L15F1/MapR1. Specific primer pairs were designed for amplification of DNA fragments (1700-1850 bp) from particular 16Sr phytoplasma groups (Table 2) for use in computer-simulated RFLP analysis (Wei et al., 2008). Primer positions are indicated in Fig. 1.

PCR amplification, cloning and sequencing of the partial spc operon. The $\sec Y$ gene was amplified from some of the phytoplasma strains listed in Table 1 belonging to different phytoplasma groups

Table 2. Primers designed in this study for amplification of the partial spc operon and DNA fragments containing the complete sec $Y$ gene and partial sequence of adjacent genes for virtual RFLP analysis

\begin{tabular}{|c|c|c|c|}
\hline $\operatorname{Primer}(\mathbf{s})$ & Sequence $(s)\left(5^{\prime}-3^{\prime}\right)$ & $\begin{array}{l}\text { 16Sr group }(s) \\
\text { amplified }\end{array}$ & $\begin{array}{c}\text { Annealing } \\
\text { temperature } \\
\left({ }^{\circ} \mathrm{C}\right)\end{array}$ \\
\hline \multicolumn{4}{|l|}{ Partial spc operon } \\
\hline L15F1/MapR1 & CCTGGTAGTGGYAMTGGWAAAAC/ATTARRAATATARGGYTCTTCRTG & $\begin{array}{l}\text { I-VIII, X, XII, XIII, } \\
\text { XVIII }\end{array}$ & 50 \\
\hline L15F1A-a/MapR1A-a & TGGWAAAACTKCBGGWAARGG/AAGMTKYACCRATDCCATG & I, XII, XIII & 55 \\
\hline L15F1A-b/MapR1A-b & $\begin{array}{l}\text { GGWAAAACYTSHGGYMRVGGHCATAAAGG/ } \\
\text { CCWATMCCRTGWCCDGWAAAA }\end{array}$ & II, III,V, VI & 64 \\
\hline L15F1A(I)/MapR1A(I) & CTTCTGGTAAAGGACATAAAGG/GTTCTTCGTGCAAAGATGTACC & I & 52 \\
\hline L15F1A(II)/MapR1A(II) & CTTGCGGTCGCGGCCATAAAGG/GGTTCTTCGTGTAAAGATTTACC & II & 60 \\
\hline L15F1A(III)/MapR1A(III) & CTTCTGGTAAAGGACATAAAGG/GGTTCTTCGTGCAATTGCAAACC & III & 55 \\
\hline L15F1A(VI)/MapR1A(VI) & CTTCAGGYAARGGTCATAAAGG/GGTTTCTTCATCAAGTCTAGTACC & VI & 50 \\
\hline L15F-646-a & TGGAARGAMCAAGGACAAAT & I, XII, XIII & 53 \\
\hline L15F-696-b & DMAAGAATGGMRWRAACAAGG & II, III,V, VI & 53 \\
\hline MapR-703-a & TYWGGTTTRTCATCTKYTCTTTG & I, XII, XIII & 53 \\
\hline MapR-696-b & AGMHACRCCDACMAYAATTA & II, III,V, VI & 48 \\
\hline L15F-806-a & SCTTTAATBGCWRCTGCWGG & I, XII, XIII & 57 \\
\hline \multicolumn{4}{|l|}{$\sec Y$ gene } \\
\hline SecYF1a/SecYR1(XII) & GGACAATTAGCWCGTTCAGG/CAGGAACTAACTTCCCTTGA & XII & 55 \\
\hline SecYF1(II)/SecYR1(II) & CGCGTATAGGTTTTGAAGGTG/CCTGCCATTTTCATTATAGCG & II & 55 \\
\hline SecYF2(II)/SecYR1(II) & TGAAGGTGGTCAAACTCCT/CCTGCCATTTTCATTATAGCG & II & 55 \\
\hline SecYF1(III)/SecYR1(III) & CTAGACCAGGTTTTGAAGG/GACCTGCTTTTCTCATTATAGC & III & 50 \\
\hline SecYF2(III)/SecYR1(III) & TGAAGGYGGACAAATCCCT/GACCTGCTTTTCTCATTATAGC & III & 55 \\
\hline SecYF1(VI)/SecYR1(VI) & CTAGATTAGGATTYGAGGG/GACCRCCAAAACCTTGATAATC & VI & 50 \\
\hline SecYF2(VI)/SecYR1(VI) & ATTYGAGGGYGGYCAAACAC/GACCRCCAAAACCTTGATAATC & VI & 55 \\
\hline $\operatorname{SecYF} 1(\mathrm{X}) / \operatorname{SecYR} 1(\mathrm{X})$ & GGTGGTGTTAGACCAGGTTT/GGAATACCYTGAACAACTAC & $\mathrm{X}$ & 50 \\
\hline SecYF2a/SecYR1(XII) & CTCTTCGMCCYGGTTTTGAAGG/CAGGAACTAACTTCCCTTGAG & XII & 55 \\
\hline
\end{tabular}


(a)

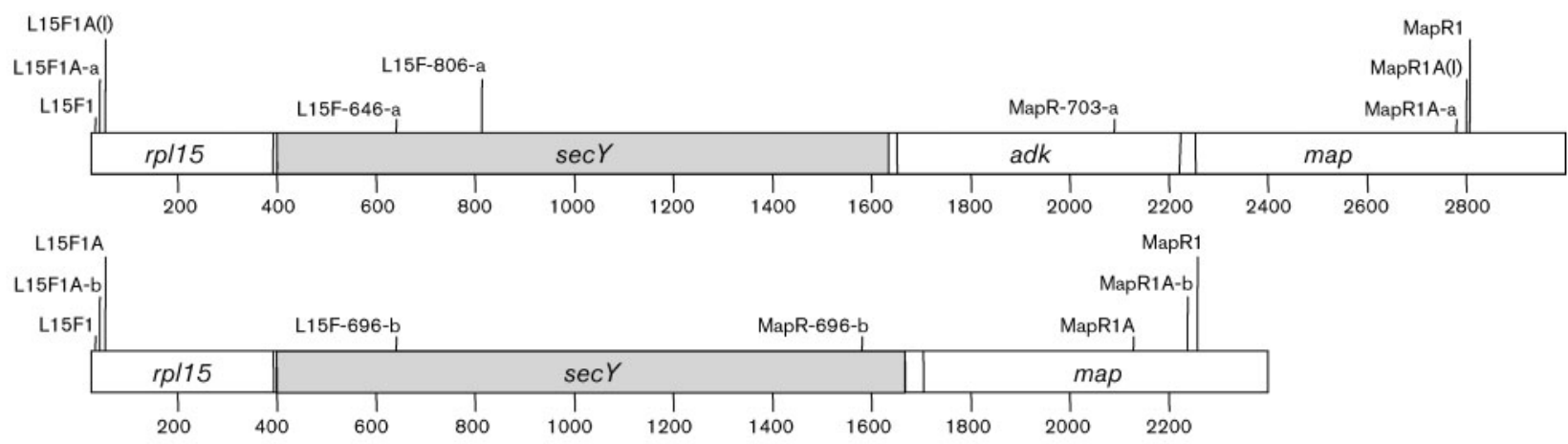

(b)

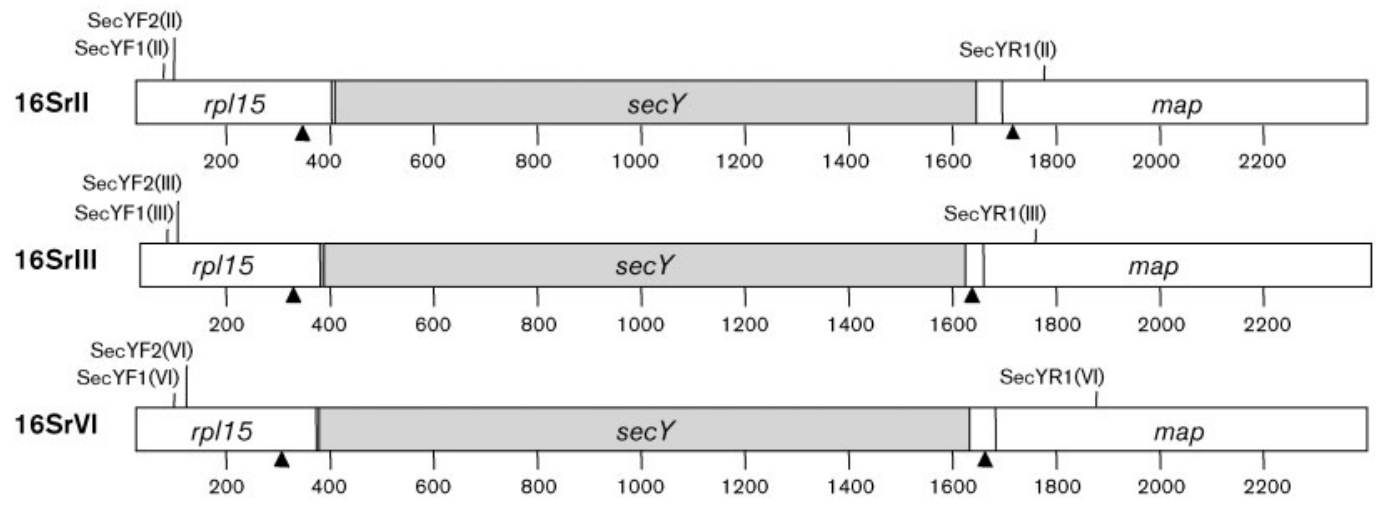

$\operatorname{SecYF1}(\mathrm{X})$

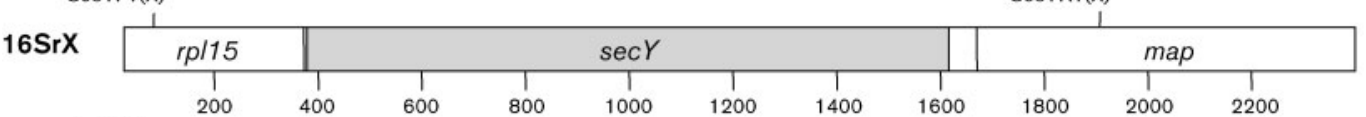

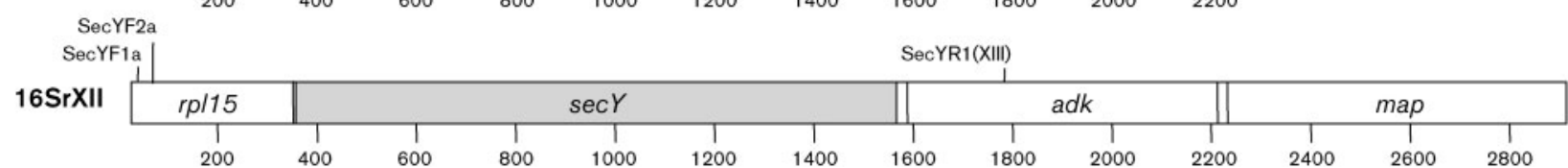

Fig. 1. Schematic gene arrangement and positions of primers designed in this study for the amplification of the partial $s p c$ operon (a) and of DNA fragments containing the complete secY gene and partial sequences of adjacent genes of selected $16 \mathrm{Sr}$ phytoplasma groups (b). $\mathbf{\Delta}$, Position to which each amplicon was trimmed for in silico RFLP analysis for phytoplasma groups $16 \mathrm{Srll}, 16 \mathrm{Srlll}$ and $16 \mathrm{SrVI}$.

using the primer pair L15F1/MapR1. The amplicon size is $2.8 \mathrm{~kb}$ for groups $16 \mathrm{SrI}, 16 \mathrm{SrXII}, 16 \mathrm{SrXIII}$ and $16 \mathrm{SrXVIII}$ and $2.2 \mathrm{~kb}$ for groups 16SrII, 16SrIII, 16SrIV, 16SrV, 16SrVI, 16SrVII and 16SrX. For PCR amplification, 35 cycles were conducted in an automated thermal cycler (MJ Research DNA thermal cycler PTC-200) with TaKaRa LA Taq polymerase (Takara Mirus Bio). PCR was performed in mixtures containing $1 \mu \mathrm{l}$ DNA extract (approx. 10-30 ng), $400 \mu \mathrm{M}$ each dNTP, $0.8 \mu \mathrm{M}$ each primer and $2.5 \mathrm{U}$ Taq polymerase. The following conditions were used: denaturation at $94{ }^{\circ} \mathrm{C}$ for $30 \mathrm{~s}(1 \mathrm{~min}$ for the first cycle), annealing for $1 \mathrm{~min}$ at $50{ }^{\circ} \mathrm{C}$ and primer extension for $5 \mathrm{~min}$ at $68{ }^{\circ} \mathrm{C}\left(10 \mathrm{~min}\right.$ in the final cycle, at $\left.72{ }^{\circ} \mathrm{C}\right)$. A negative control devoid of DNA template in the reaction mixture was included in all PCRs. Aliquots of the PCR products $(3 \mu \mathrm{l})$ were electrophoresed through a $1 \%$ agarose gel, stained with ethidium bromide and visualized with a UV transilluminator. The amplicons were purified using PCR Kleen spin columns (Bio-Rad) or, for amplicons with multiple bands, the QIAquick gel extraction kit (Qiagen) according to the manufacturers' instructions. The majority of purified products were cloned into Escherichia coli TOP10 by using the TOPO TA cloning kit (Invitrogen) according to the manufacturer's instructions and sequenced with an automated DNA sequencer (ABI Prism model 3730) at the Center for Biosystems Research (University of Maryland, College Park, MD, USA) using SP6 and T7 promoter primers. For purified products with a low concentration, direct sequencing with L15F1/MapR1 primers was performed. Additional walking primers were needed to determine the complete nucleotide sequence. For $16 \mathrm{Sr}$ groups I, XII, XIII and XVIII, the walking primers used were L15F646-a, L15F-806-a and MapR-703-a. For all other 16Sr groups, the walking primers used were L15F-696-b and MapR-696-b (Table 2). Other primers listed in Table 2 were used to amplify additional $16 \mathrm{Sr}$ phytoplasma groups for sequencing according to the procedure described above. All sequences were submitted to GenBank; accession numbers are listed in Table 1.

Phylogenetic analysis. $\sec Y$ nucleotide and deduced amino acid sequences and $16 \mathrm{~S}$ rRNA gene sequences from 83 and 80 phytoplasma strains, respectively, representative of 12 distinct phytoplasma $16 \mathrm{Sr}$ groups (consisting of more than $4016 \mathrm{Sr}$ subgroups) and from two 


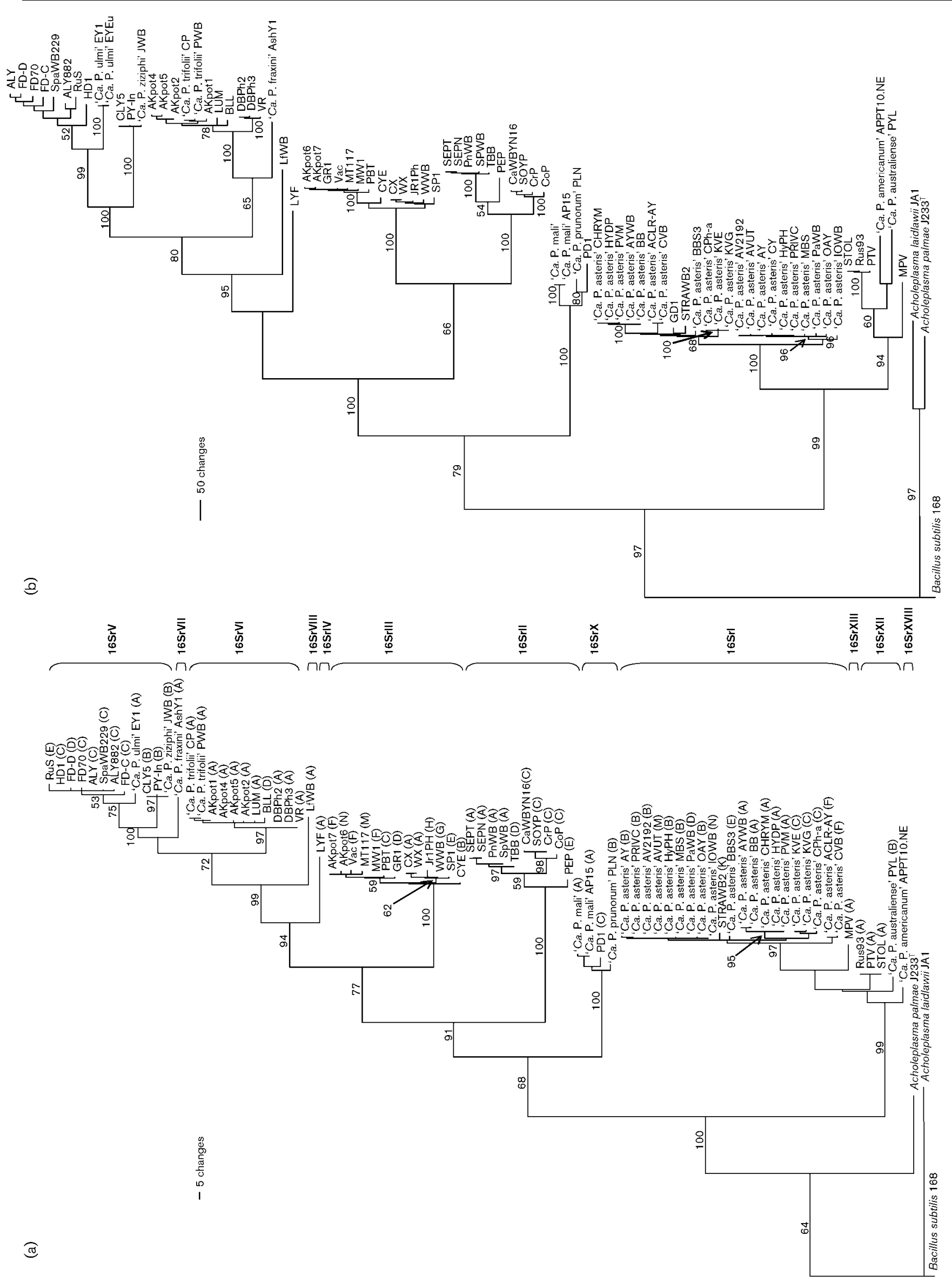


Acholeplasma strains and Bacillus subtilis 168 were aligned using CLUSTAL $v$ from the LaserGene software MEGALIGN program (DNASTAR). Cladistic analyses were performed with PAUP version 4.0 (Swofford, 1998) on a Power Mac G4. Uninformative characters were excluded from analyses. Phylogenetic trees were constructed by a heuristic search (or neighbour-joining algorithm) by random stepwise addition, implementing the tree bisection and reconnection branchswapping algorithm to find the optimal tree(s) (Gundersen et al., 1994). B. subtilis 168 was used as the outgroup to root the trees. The analysis was replicated 1000 times. Bootstrapping was performed to estimate the stability and support for the inferred clades. Full-length $\sec Y$ and near full-length $(1.43 \mathrm{~kb}) 16 \mathrm{~S}$ rRNA gene sequences of phytoplasma strains used for phylogenetic analysis were either sequenced in this work or obtained from the GenBank database.

\section{Strain differentiation by computer-simulated RFLP analysis of $\sec Y$ sequences. To demonstrate the efficacy of using the $\sec Y$ gene sequence for finer differentiation of phytoplasma strains, DNA fragments ranging from 1700 to $1850 \mathrm{bp}$ containing the entire $\sec Y$ gene and partial sequences of adjacent genes ( $r p l 15$ and map) were amplified using nested PCR and sequenced from phytoplasma strains in groups 16SrII, $16 \mathrm{SrIII}$ and 16SrVI using specific primers listed in Table 2. These sequences were trimmed to about $1.4,1.34$ and $1.37 \mathrm{~kb}$ for groups 16SrII, 16SrIII and 16SrVI, respectively, each of which contains the complete $\sec Y$ gene and partial rpll5 and map genes or intergenic spacer regions, for in silico RFLP analysis (Fig. 1b). Collective RFLP pattern types of full-length phytoplasma $\sec Y$ gene sequences were based on analysis by 18 restriction enzymes. In silico restriction digestion and pairwise virtual RFLP pattern comparison were performed using a modified Perl program developed previously (Wei et al., 2008), with the inclusion of an additional restriction enzyme, Tsp509I. Virtual gel images were generated using the program VGelME. Key enzymes that distinguish different (group/ subgroup) pattern types were identified by using the program VGelMS. The programs VGelME and VGelMS were described previously (Zhao et al., 2009).}

\section{RESULTS AND DISCUSSION}

\section{Amplification of the partial phytoplasma spc operon}

A partial $s p c$ ribosomal protein operon from each of 50 phytoplasma strains representing $1216 \mathrm{Sr}$ groups was amplified by PCR and sequenced. Annotated sequences revealed the presence of two distinct $s p c$ operons among the phytoplasma strains analysed. Strains belonging to groups 16 SrI, 16SrXII, 16 SrXIII and 16 SrXVIII had an spc operon with the gene order rpl15-secY-adk-map, while strains belonging to groups 16SrII, 16SrIII, $16 \mathrm{SrIV}, 16 \mathrm{SrV}$, 16SrVI, 16SrVII, 16SrVIII and 16SrX had an operon with the gene order rpl15-secY-map, lacking the gene adk. The distinctness of the two $s p c$ operon types separated phytoplasmas into two major subclades, which seem to coincide with the divergence of the two major phylogenetic groups from an Acholeplasma-like ancestor early in the course of evolution, as shown on phylogenetic trees constructed previously and in this study based on $16 \mathrm{~S}$ rRNA, ribosomal protein and $\sec Y$ gene sequences. This finding of two heterogeneous $s p c$ operons in 'Candidatus Phytoplasma' may have implications for phytoplasma evolution. Members of the genus Acholeplasma, the closest known relatives of phytoplasmas, and strains in the Clostridium/Lactobacillus group, believed to contain the common ancestor of the class Mollicutes, have an $s p c$ operon with a gene order identical to that found in phytoplasma strains belonging to groups 16SrI, 16SrXII, 16SrXIII and 16SrXVIII. This implies that phytoplasma strains in groups lacking the adk gene may have diverged from the phytoplasma common ancestor, which is most closely related to Acholeplasma species, during the course of phytoplasma evolution. Phylogenies based on $\sec Y$, $16 \mathrm{~S}$ rRNA and ribosomal protein gene sequences also support this suggestion.

\section{Phylogenetic interrelationships and genetic variations of phytoplasmas based on nucleotide sequences of the secY gene}

The phylogenetic analyses resulted in 77 equally parsimonious trees based on $\sec Y$ nucleotide sequences and 82 trees based on deduced SecY amino acid sequences. The trees inferred from the $\sec Y$ gene had a topology similar to that based on deduced SecY amino acid sequences (not shown). One representative parsimonious tree inferred from the $\sec Y$ gene was selected (Fig. 2). There were two subclades within the phytoplasma clade: one comprised strains in groups 16SrI, 16SrXII, 16SrXIII and 16SrXVIII and the other comprised strains in the remainder of the groups analysed in this study. The latter subclade comprised two major branches: one included strains in group $16 \mathrm{SrX}$ and the other contained strains in groups 16SrII, 16SrIII, 16SrIV, 16SrV, 16SrVI, 16SrVII, 16SrVIII and 16SrIX. The interrelatedness among phytoplasma taxa inferred from $\sec Y$ gene-based phylogeny was nearly congruent with that inferred from 16S rRNA gene-based phylogenies shown in this study and reported previously (Lee et al., 1998a, 2000; Seemüller et al., 1998; Jung et al., 2002; Martini et al., 2007). Clearly, phylogenetic analysis based on $\sec Y$ gene sequences permitted finer differentiation of phytoplasma strains. The secY gene-based phylogeny readily resolved subgroups within a given $16 \mathrm{Sr}$ group, and also delineated distinct lineages irresolvable by $16 \mathrm{~S}$ rRNA gene-based phylogeny. For example, members in each of groups $16 \mathrm{SrV}$, 16 SrII and 16SrIII clearly represented two distinct genetically divergent lineages, as supported by high bootstrap

Fig. 2. Phylogenetic trees constructed by parsimony analyses of partial $16 \mathrm{~S}$ rRNA (a) and full secY (b) gene sequences from phytoplasma strains representative of 12 distinct phytoplasma $16 \mathrm{Sr}$ groups (consisting of more than $4016 \mathrm{Sr}$ subgroups) and from two Acholeplasma strains and Bacillus subtilis. B. subtilis 168 was used as the outgroup to root the trees. Branch lengths are proportional to the number of inferred character state transformations. Bootstrap values are shown on the main branches. Bars, 5 (a) and 50 (b) inferred character state changes. 16Sr groups are indicated; subgroup affiliations are indicated in parentheses in (a). Phytoplasma strain abbreviations are defined in Table 1. 
values, which were not well resolved by $16 \mathrm{~S}$ rRNA genebased phylogenetic analysis.

\section{Genetic variations of phytoplasmas assessed by comparative sequence analyses of secY and $16 S$ rRNA genes}

The $\sec Y$ gene nucleic acid sequence similarity between members of different phytoplasma groups ranged from 53.5 to $77.9 \%$, compared with $85.1-96.9 \%$ for $16 \mathrm{~S}$ rRNA gene sequences. Examples are members of the PnWB group (16SrII) analysed in this study, where the sequence similarity ranged from 87.7 to $100 \%$ for the $\sec Y$ gene and 97.4 to $99.6 \%$ for the $16 \mathrm{~S}$ rRNA gene. Among members of the $\mathrm{X}$-disease (16SrIII) group, sequence similarities ranged from 93.6 to $99.8 \%$ for the $\sec Y$ gene and 99.0 to $99.8 \%$ for the $16 \mathrm{~S}$ rRNA gene, whereas, among members of the clover proliferation (16SrVI) group, the sequence similarities ranged from 94.4 to $99.8 \%$ for the $\sec Y$ gene and 98.4 to $99.2 \%$ for the $16 \mathrm{~S}$ rRNA gene. The greater sequence variability indicates that the $\sec Y$ gene is a more informative molecular tool for classification of closely related phytoplasma strains.

\section{Strain differentiation by virtual RFLP analysis of $\sec Y$ sequences}

The relatively variable $\sec Y$ gene sequences should be highly useful in RFLP analysis for finer differentiation of ecologically or biologically distinct strains within a given

Table 3. Summary of profiles produced by virtual RFLP analyses of the secY gene from phytoplasma $16 \mathrm{Sr}$ groups II, III and VI

\begin{tabular}{|c|c|c|c|c|c|c|c|c|c|c|c|c|c|}
\hline \multirow[t]{2}{*}{ Strain } & \multirow[t]{2}{*}{ Subgroup } & \multicolumn{12}{|c|}{ RFLP pattern type } \\
\hline & & $A l u \mathrm{I}$ & $B f a I$ & DraI & HaeIII & HinfI & HpaII & MseI & RsaI & Sau3AI & SspI & $\operatorname{Taq} \mathrm{I}$ & $T s p 509 \mathrm{I}$ \\
\hline \multicolumn{14}{|l|}{ Group 16SrII } \\
\hline PnWB & A & 1 & 1 & 1 & 1 & 1 & 1 & 1 & 1 & 1 & 1 & 1 & 1 \\
\hline SPWB & $\mathrm{A}$ & 1 & 2 & 2 & 1 & 1 & 1 & 1 & 1 & 1 & 1 & 1 & 1 \\
\hline SEPT & $\mathrm{A}$ & 1 & 1 & 2 & 1 & 1 & 1 & 1 & 1 & 1 & 1 & 1 & 1 \\
\hline SEPN & A & 1 & 1 & 2 & 1 & 1 & 1 & 1 & 1 & 1 & 1 & 1 & 1 \\
\hline CacWBYN16 & $\mathrm{C}$ & 2 & 3 & 3 & 2 & 2 & 2 & 2 & 2 & 2 & 2 & 1 & 2 \\
\hline SOYP & $\mathrm{C}$ & 2 & 3 & 3 & 2 & 2 & 2 & 2 & 2 & 3 & 2 & 1 & 2 \\
\hline $\mathrm{CrP}$ & $\mathrm{C}$ & 2 & 3 & 3 & 2 & 2 & 3 & 2 & 2 & 2 & 2 & 1 & 2 \\
\hline $\mathrm{CoP}$ & $\mathrm{C}$ & 3 & 3 & 4 & 1 & 2 & 2 & 2 & 2 & 2 & 2 & 1 & 2 \\
\hline TBB & $\mathrm{D}$ & 1 & 1 & 1 & 1 & 1 & 1 & 1 & 1 & 1 & 1 & 1 & 1 \\
\hline PEP & $\mathrm{E}$ & 4 & 4 & 5 & 3 & 3 & 2 & 3 & 3 & 4 & 3 & 2 & 3 \\
\hline \multicolumn{14}{|l|}{ Group 16SrIII } \\
\hline $\mathrm{CX}$ & A & 1 & 1 & 1 & 1 & 1 & 1 & 1 & 1 & 1 & 1 & 1 & 1 \\
\hline WX & $\mathrm{A}$ & 1 & 1 & 1 & 1 & 1 & 1 & 2 & 1 & 1 & 1 & 1 & 1 \\
\hline CYE & B & 2 & 2 & 2 & 1 & 2 & 2 & 3 & 2 & 1 & 2 & 1 & 2 \\
\hline $\mathrm{Vac}$ & $\mathrm{F}$ & 3 & 2 & 1 & 2 & 3 & 2 & 4 & 1 & 1 & 2 & 1 & 3 \\
\hline PBT & $\mathrm{C}$ & 4 & 2 & 1 & 1 & 4 & 3 & 5 & 1 & 1 & 2 & 1 & 4 \\
\hline GR1 & $\mathrm{D}$ & 3 & 2 & 1 & 2 & 3 & 2 & 4 & 1 & 1 & 2 & 1 & 3 \\
\hline SP1 & $\mathrm{E}$ & 5 & 3 & 1 & 1 & 1 & 1 & 6 & 3 & 1 & 1 & 1 & 5 \\
\hline MW1 & F & 6 & 2 & 1 & 1 & 3 & 2 & 4 & 1 & 1 & 2 & 1 & 3 \\
\hline AKpot7 & $\mathrm{F}$ & 3 & 2 & 1 & 2 & 3 & 2 & 4 & 1 & 1 & 2 & 1 & 6 \\
\hline WWB & G & 1 & 1 & 1 & 1 & 1 & 1 & 7 & 1 & 1 & 1 & 1 & 7 \\
\hline $\mathrm{JR} 1 \mathrm{Ph}$ & $\mathrm{H}$ & 2 & 1 & 1 & 1 & 1 & 1 & 1 & 1 & 1 & 1 & 1 & 1 \\
\hline MT117 & M & 3 & 2 & 1 & 2 & 3 & 2 & 4 & 1 & 1 & 2 & 1 & 3 \\
\hline AKpot6 & $\mathrm{N}$ & 3 & 2 & 1 & 2 & 3 & 2 & 4 & 1 & 1 & 2 & 1 & 7 \\
\hline \multicolumn{14}{|l|}{ Group 16SrVI } \\
\hline $\mathrm{CP}$ & A & 1 & 1 & 1 & 1 & 1 & 1 & 1 & 1 & 1 & 1 & 1 & 1 \\
\hline PWB & A & 1 & 1 & 1 & 1 & 1 & 1 & 1 & 1 & 1 & 1 & 2 & 1 \\
\hline AKpot1 & $\mathrm{A}$ & 1 & 1 & 1 & 1 & 1 & 1 & 1 & 1 & 1 & 1 & 1 & 1 \\
\hline AKpot4 & A & 1 & 1 & 1 & 1 & 1 & 1 & 2 & 2 & 1 & 2 & 1 & 1 \\
\hline AKpot5 & $\mathrm{A}$ & 1 & 1 & 1 & 1 & 1 & 1 & 2 & 2 & 1 & 2 & 1 & 1 \\
\hline AKpot2 & $\mathrm{A}$ & 1 & 1 & 1 & 1 & 1 & 1 & 2 & 2 & 1 & 2 & 1 & 1 \\
\hline LUM & A & 2 & 1 & 1 & 1 & 1 & 1 & 3 & 1 & 1 & 1 & 3 & 2 \\
\hline $\mathrm{DBPh} 2$ & A & 3 & 1 & 1 & 1 & 2 & 1 & 4 & 1 & 1 & 3 & 1 & 3 \\
\hline $\mathrm{DBPh} 3$ & A & 3 & 1 & 1 & 1 & 2 & 1 & 4 & 1 & 1 & 3 & 1 & 3 \\
\hline VR & A & 3 & 1 & 1 & 1 & 2 & 1 & 4 & 1 & 1 & 3 & 4 & 3 \\
\hline BLL & $\mathrm{D}$ & 2 & 2 & 1 & 1 & 1 & 1 & 2 & 1 & 1 & 1 & 1 & 4 \\
\hline
\end{tabular}


$16 \mathrm{Sr}$ phytoplasma group. To evaluate the efficacy of the $\sec Y$ gene for finer differentiation of phytoplasma strains, computer-simulated virtual RFLP patterns were generated using iPhyClassifier (Zhao et al., 2009). Table 3 summarizes the collective pattern types of strains analysed in groups 16SrII, 16SrIII and 16SrVI using 12 key restriction enzymes among the 18 used for analysis. Biologically distinct strains within a given $16 \mathrm{Sr}$ group and, in most cases, $16 \mathrm{Sr}$ subgroup were readily differentiated based on collective patterns. For example, ten members of subgroup 16SrVI-A were differentiated into seven $\sec Y(\mathrm{VI})$ genotypes represented by the following individual strains or strain clusters: CP and AKpot1; AKpot2, AKpot4 and AKpot5; DBPh2 and DBPh3; PWB; LUM; BLL; and VR. Four members of subgroup 16SrII-A (SEPT, SEPN, PnWB and SPWB) were differentiated into three $\sec Y(\mathrm{II})$ genotypes, with two strains, SEPT and SEPN, having the same genotype. Four members of subgroup 16SrII-C (CaWBYN16, SOYP, CrP and CoP) were differentiated into four $\sec Y(\mathrm{II})$ genotypes. However, in one case, two different $16 \mathrm{Sr}$ subgroups were found to have similar $\sec Y$ genotypes; AKpot6 and AKpot7, which are classified as
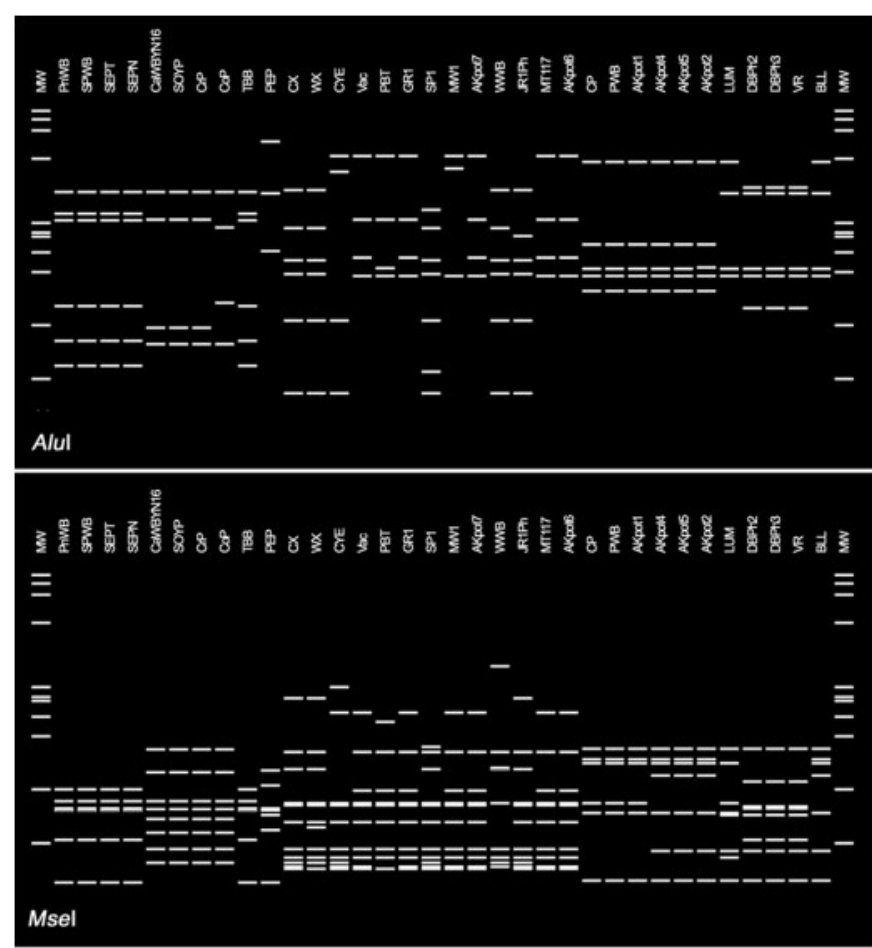

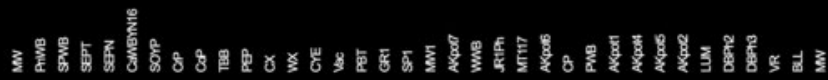

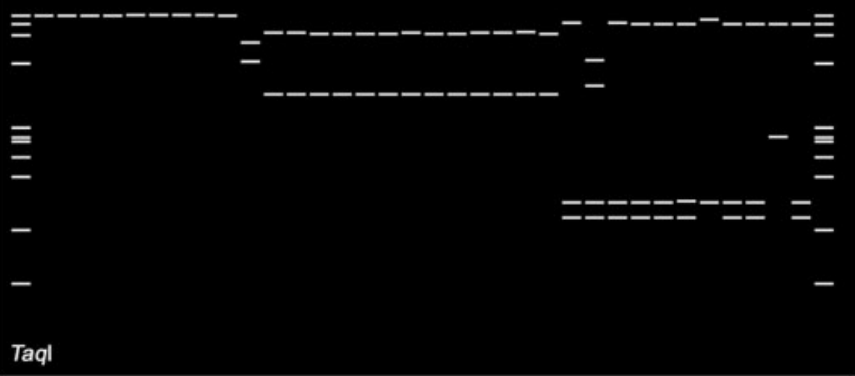

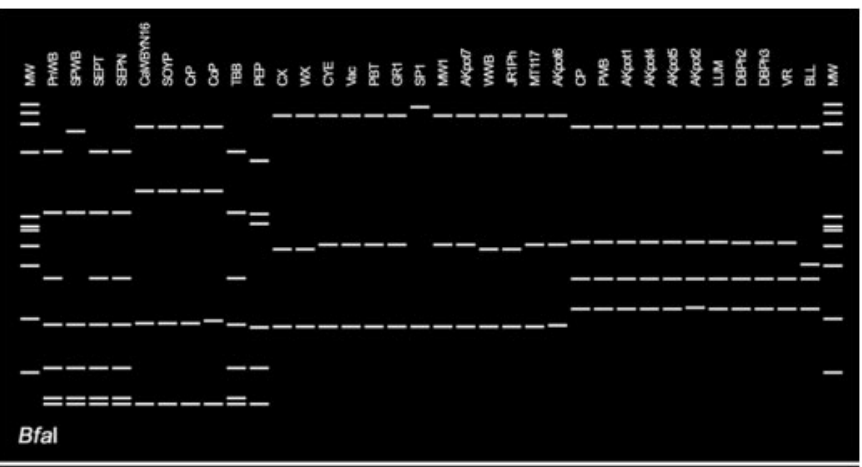
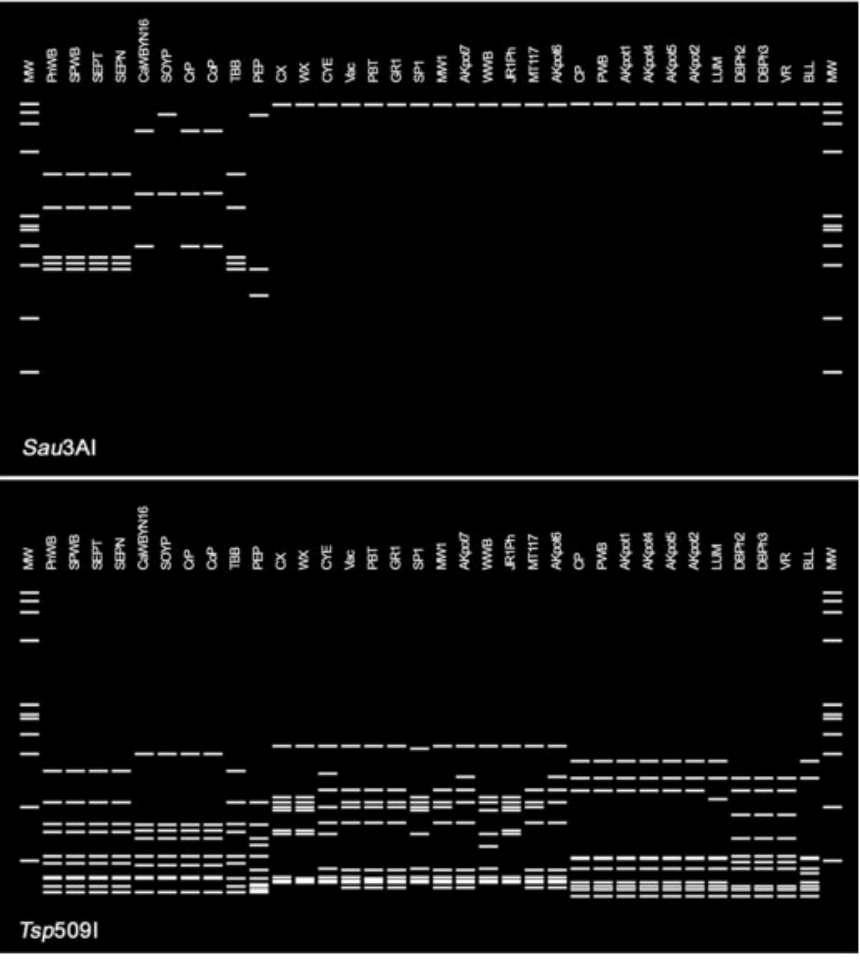

Fig. 3. Computer-simulated virtual RFLP patterns derived from in silico digestions of phytoplasma sec $Y$ gene fragments (about $1.4,1.34$ and $1.37 \mathrm{~kb}$, respectively, for groups $16 \mathrm{Srll}, 16 \mathrm{Srlll}$ and $16 \mathrm{SrVI}$ ) from representative strains of groups $16 \mathrm{Srll}, 16 \mathrm{Srlll}$ and 16SrVI with six key enzymes: Alul, Bfal, Msel, Sau3Al, Taql and Tsp509I. Lanes MW, Haell digest of $\phi$ X174 RFI DNA; fragment sizes (bp) from top to bottom: 1353, 1078, 872, 603, 310, 281, 271, 234, 194, 118, 72. Phytoplasma strain abbreviations are defined in Table 1. Subgroup affiliations: PnWB, SPWB, SEPT and SEPN, 16Srll-A; CaWBYN16, SOYP, CrP and CoP, 16Srll-C; TBB, 16Srll-D; PEP, 16Srll-E; CX and WX, 16Srlll-A; CYE, 16Srlll-B; PBT, 16Srlll-C; GR1, 16Srlll-D; SP1, 16Srlll-E; Vac, MW1 and AKpot7, 16Srlll-F; WWB, 16Srlll-G; JRPh1, 16Srlll-H; MT117, 16Srlll-M; AKpot6, 16Srlll-N; CP, PWB, AKpot1, AKpot4, AKpot5, AKpot2, LUN, DBPh2, DBPh3 and VR, 16SrVI-A; BLL, 16SrVI-D. 
16SrIII-N and 16SrIII-F, respectively, have a similar $\sec Y$ (III) genotype. Fig. 3 shows computer-simulated virtual gel patterns with six key enzymes (AluI, HpaII, MseI, RsaI, TaqI and Tsp509I). Greater sequence variability in the $\sec Y$ gene provides additional genetic markers that increase the resolving power substantially for differentiation of subgroups within a given $16 \mathrm{Sr}$ group. Using $\sec Y$, it is feasible to separate closely related, but biologically or geographically distinct, strain variants within a given subgroup. The genetic variability among subgroups in a given 16Sr group was reinforced in general while, in some cases, two $16 \mathrm{Sr}$ subgroups revealed little or no variability in the $\sec Y$ gene. Discrepancies in determining the genetic variability of closely related strains based on the $16 \mathrm{~S}$ rRNA gene can only be resolved by incorporating multiple genes with varying degrees of genetic variability in analyses. Many 16Sr subgroups appear to have significant biological implications. In many subgroups, the constituent strains are often associated with specific plant hosts and have specific vector interrelationships in nature, while, in some subgroups, the constituent members are genetically diverse and are often associated with multiple plant hosts and insect vectors (Lee et al., 2004b). Identification of biologically distinct strains is essential and highly relevant for epidemiological studies.

\section{Conclusion}

A classification system based on the highly conserved $16 \mathrm{~S}$ rRNA gene sequence is insufficient for fine differentiation of closely related phytoplasma strains, underscoring the urgent need to utilize additional molecular markers that exhibit moderate genetic variability. The $\sec Y$ gene, located in the operator-distal part of the $s p c$ ribosomal protein operon, encodes protein translocase subunit SecY. A single copy of the $\sec Y$ gene is present in all known phytoplasma genomes. The $\sec Y$ gene is one of the most variable among the phylogenetic markers used so far for differentiation of phytoplasma strains and was found to be more efficient than other gene markers for differentiation and classification of phytoplasmas and especially for resolving closely related strains within the same 16S rRNA gene RFLP group (Hodgetts et al., 2008; Lee et al., 2006a; Martini et al., 2007).

In the present study, $\sec Y$ gene-based phylogeny revealed new insights into the phylogenetic relationships among phytoplasma strains. Being more variable than the $16 \mathrm{~S}$ rRNA gene, $\sec Y$ provided more phylogenetically informative markers useful for differentiation of genetically closely related but ecologically distinct strains, not readily separated by analysis of the $16 \mathrm{~S}$ rRNA gene. The $16 \mathrm{~S}$ rRNA gene has been the primary phylogenetic marker used for delineation of major phytoplasma groups and candidate species within 'Candidatus Phytoplasma'. However, finer differentiation of strains into subgroups cannot be achieved on the basis of the rather limited variable regions present in the 16S rRNA gene. Including the 16S rRNA gene in combination with an additional marker that displays moderate genetic variability in phylogenetic analysis overcomes the limitations of the 16S rRNA gene for classification of phytoplasma strains below the species level. The present study and our previous studies (Lee et al., 2006a; Martini et al., 2002, 2007) indicate that phylogenetic analyses based on moderately variable genes, such as $\sec Y$ or ribosomal protein genes, increased the resolving power substantially for delineation of 16S rRNA groups and subgroups and for closely related but biologically distinct strains. For example, strain MBS, strains FD-C, ALY and SpaWB and strains DBPh2, DBPh3 and VR can be differentiated readily from other members of groups $16 \mathrm{SrIB}, 16 \mathrm{SrV}$ and $16 \mathrm{SrVI}$, respectively. These strains inhabit mutually distinct ecological niches (Table 1). Emerging multiple-gene-based classification systems should provide molecular criteria for improved delineation of species and strains.

\section{ACKNOWLEDGEMENTS}

We thank all the individuals who provided phytoplasma strains used in this study. We thank Wei Wei for her assistance in preparing in silico RFLP images. We also thank Prachi Bagadia for her technical assistance in sequence assembly and phylogenetic analysis.

\section{REFERENCES}

Bertaccini, A. (2007). Phytoplasmas: diversity, taxonomy, and epidemiology. Front Biosci 12, 673-689.

Cai, H., Wei, W., Davis, R. E., Chen, H. \& Zhao, Y. (2008). Genetic diversity among phytoplasmas infecting Opuntia species: virtual RFLP analysis identifies new subgroups in the peanut witches'-broom phytoplasma group. Int J Syst Evol Microbiol 58, 1448-1457.

Green, M. J., Thompson, D. A. \& MacKenzie, D. J. (1999). Easy and efficient DNA extraction from woody plants for the detection of phytoplasmas by polymerase chain reaction. Plant Dis $\mathbf{8 3}, 482-485$.

Gundersen, D. E., Lee, I.-M., Rehner, S. A., Davis, R. E. \& Kingsbury, D. T. (1994). Phylogeny of mycoplasmalike organisms (phytoplasmas): a basis for their classification. J Bacteriol 176, 5244-5254.

Hodgetts, J., Boonham, N., Mumford, R., Harrison, N. \& Dickinson, M. (2008). Phytoplasma phylogenetics based on analysis of $\sec A$ and $23 \mathrm{~S}$ rRNA gene sequences for improved resolution of candidate species of 'Candidatus Phytoplasma'. Int J Syst Evol Microbiol 58, 1826-1837.

Hogenhout, S. A., Oshima, K., Ammar, E.-D., Kakizawa, S., Kingdom, H. N. \& Namba, S. (2008). Phytoplasmas: bacteria that manipulate plants and insects. Mol Plant Pathol 9, 403-423.

IRPCM Phytoplasma/Spiroplasma Working Team - Phytoplasma Taxonomy Group (2004). 'Candidatus Phytoplasma', a taxon for the wall-less, non-helical prokaryotes that colonize plant phloem and insects. Int J Syst Evol Microbiol 54, 1243-1255.

Jacobs, K. A., Lee, I.-M., Griffiths, H. M., Miller, F. D., Jr \& Bottner, K. D. (2003). A new member of the clover proliferation phytoplasmas group $(16 \mathrm{SrVI})$ associated with elm yellows in Illinois. Plant Dis 87, 241-246.

Jung, H. Y., Sawayanagi, T., Kakizawa, S., Nishigawa, H., Miyata, S., Oshima, K., Ugaki, M., Lee, J. T., Hibi, T. \& Namba, S. (2002).

'Candidatus Phytoplasma castaneae', a novel phytoplasma taxon 
associated with chestnut witches' broom disease. Int J Syst Evol Microbiol 52, 1543-1549.

Lee, I.-M., Davis, R. E., Sinclair, W. A., DeWitt, N. D. \& Conti, M. (1993a). Genetic relatedness of mycoplasmalike organisms detected in Ulmus spp. in the United States and Italy by means of DNA probes and polymerase chain reactions. Phytopathology 83, 829-833.

Lee, I.-M., Hammond, R. W., Davis, R. E. \& Gundersen, D. E. (1993b). Universal amplification and analysis of pathogen 16S rDNA for classification and identification of mycoplasmalike organisms. Phytopathology 83, 834-842.

Lee, I.-M., Gundersen-Rindal, D. E., Davis, R. E. \& Bartoszyk, I. M. (1998a). Revised classification scheme of phytoplasmas based on RFLP analyses of $16 \mathrm{~S}$ rRNA and ribosomal protein gene sequences. Int J Syst Bacteriol 48, 1153-1169.

Lee, I.-M., Gundersen-Rindal, D. E. \& Bertaccini, A. (1998b). Phytoplasma: ecology and genomic diversity. Phytopathology 88, 1359-1366.

Lee, I.-M., Davis, R. E. \& Gundersen-Rindal, D. E. (2000). Phytoplasma: phytopathogenic mollicutes. Annu Rev Microbiol 54, 221-255.

Lee, I.-M., Martini, M., Bottner, K. D., Dane, R. A., Black, M. C. \& Troxclair, N. (2003). Ecological implications from a molecular analysis of phytoplasmas involved in an aster yellows epidemic in various crops in Texas. Phytopathology 93, 1368-1377.

Lee, I.-M., Martini, M., Marcone, C. \& Zhu, S. F. (2004a). Classification of phytoplasma strains in the elm yellows group (16SrV) and proposal of 'Candidatus Phytoplasma ulmi' for the phytoplasma associated with elm yellows. Int J Syst Evol Microbiol 54, 337-347.

Lee, I.-M., Gundersen-Rindal, D. E., Davis, R. E., Bottner, K. D., Marcone, C. \& Seemüller, E. (2004b). 'Candidatus Phytoplasma asteris', a novel phytoplasma taxon associated with aster yellows and related diseases. Int J Syst Evol Microbiol 54, 1037-1048.

Lee, I.-M., Bottner, K. D., Munyaneza, J. E., Secor, G. A. \& Gudmestad, N. C. (2004c). Clover proliferation group (16SrVI) subgroup A (16SrVI-A) phytoplasma is a probable causal agent of potato purple top disease in Washington and Oregon. Plant Dis 88, 429.

Lee, I.-M., Zhao, Y. \& Bottner, K. D. (2006a). SecY gene sequence analysis for finer differentiation of diverse strains in the aster yellows phytoplasma group. Mol Cell Probes 20, 87-91.

Lee, I.-M., Bottner, K. D., Secor, G. \& Rivera-Varas, V. (2006b). 'Candidatus Phytoplasma americanum', a phytoplasma associated with a potato purple top wilt disease complex. Int J Syst Evol Microbiol 56, 1593-1597.

Marcone, C., Ragozzino, A. \& Seemüller, E. (1997a). Detection and identification of phytoplasmas in yellows-diseased weeds in Italy. Plant Pathol 46, 530-537.

Marcone, C., Ragozzino, A. \& Seemüller, E. (1997b). Identification and characterization of the phytoplasma associated with elm yellows in southern Italy and its relatedness to other phytoplasmas of the elm yellows group. Eur J Forest Pathol 27, 45-54.

Marcone, C., Ragozzino, A. \& Seemüller, E. (1997c). Detection and identification of phytoplasmas infecting vegetable, ornamental and forage crops in southern Italy. J Plant Pathol 79, 211-217.

Marcone, C., Lee, I.-M., Davis, R. E., Ragozzino, A. \& Seemüller, E. (2000). Classification of aster yellows-group phytoplasmas based on combined analyses of rRNA and tuf gene sequences. Int J Syst Evol Microbiol 50, 1703-1713.

Martini, M., Botti, S., Marcone, C., Marzachì, C., Casati, P., Bianco, P. A., Benedetti, R. \& Bertaccini, A. (2002). Genetic variability among Flavescence dorée phytoplasmas from different origins in Italy and France. Mol Cell Probes 16, 197-208.

Martini, M., Lee, I.-M., Bottner, K. D., Zhao, Y., Botti, S., Bertaccini, A., Harrison, N. A., Carraro, L., Marcone, C. \& other authors (2007). Ribosomal protein gene-based phylogeny for finer differentiation and classification of phytoplasmas. Int J Syst Evol Microbiol 57, 2037-2051.

Murray, R. G. E. \& Schleifer, K. H. (1994). Taxonomic notes: a proposal for recording the properties of putative taxa of procaryotes. Int J Syst Bacteriol 44, 174-176.

Razin, S., Yogev, D. \& Naot, Y. (1998). Molecular biology and pathology of mycoplasmas. Microbiol Mol Biol Rev 62, 1094-1156.

Schneider, B., Seemüller, E., Smart, C. D. \& Kirkpatrick, B. C. (1995). Phylogenetic classification of plant pathogenic mycoplasmalike organisms or phytoplasmas. In Molecular and Diagnostic Procedures in Mycoplasmology, vol. 1, pp. 369-380. Edited by R. Razin \& J. G. Tully. San Diego: Academic Press.

Schneider, B., Marcone, C., Kampmann, M., Ragozzino, A., Lederer, W., Cousin, M. T. \& Seemüller, E. (1997). Characterization and classification of phytoplasmas from wild and cultivated plants by RFLP and sequence analysis of ribosomal DNA. Eur J Plant Pathol 103, 675-686.

Seemüller, E., Schneider, B., Mäurer, R., Ahrens, U., Daire, X., Kison, H., Lorenz, K. H., Firrao, G., Avinent, L. \& other authors (1994). Phylogenetic classification of phytopathogenic mollicutes by sequence analysis of $16 S$ ribosomal DNA. Int J Syst Bacteriol 44, 440-446.

Seemüller, E., Marcone, C., Lauer, U., Ragozzino, A. \& Göschl, M. (1998). Current status of molecular classification of the phytoplasmas. J Plant Pathol 80, 3-26.

Suh, J.-W., Boylan, S. A., Oh, S.-H. \& Price, C. W. (1996). Genetic and transcriptional organization of the Bacillus subtilis spc- $\alpha$ region. Gene 169, 17-23.

Swofford, D. L. (1998). Phylogenetic analysis using parsimony (PAUP), version 4. Sunderland, MA: Sinauer Associates.

Vandamme, P., Pot, B., Gillis, M., De Vos, P., Kersters, K. \& Swings, J. (1996). Polyphasic taxonomy, a consensus approach to bacterial systematics. Microbiol Rev 60, 407-438.

Wei, W., Davis, R. E., Lee, I.-M. \& Zhao, Y. (2007). Computersimulated RFLP analysis of 16S rRNA genes: identification of ten new phytoplasma groups. Int J Syst Evol Microbiol 57, 18551867.

Wei, W., Lee, I.-M., Davis, R. E., Suo, X. \& Zhao, Y. (2008). Automated RFLP pattern comparison and similarity coefficient calculation for rapid delineation of new and distinct phytoplasma $16 \mathrm{Sr}$ subgroup lineages. Int J Syst Evol Microbiol 58, 2368-2377.

Weisburg, W. G., Tully, J. G., Rose, D. L., Petzel, J. P., Oyaizu, H., Yang, D., Mandelco, L., Sechrest, J., Lawrence, T. G. \& other authors (1989). A phylogenetic analysis of the mycoplasmas: basis for their classification. J Bacteriol 171, 6455-6467.

Zhao, Y., Wei, W., Lee, I.-M., Shao, J., Suo, X. \& Davis, R. E. (2009). Construction of an interactive online phytoplasma classification tool, $i$ PhyClassifier, and its application in analysis of the peach X-disease phytoplasma group (16SrIII). Int J Syst Evol Microbiol 59, 2582-2593. 